\title{
Insights into Migration and Development of Coral Black Band Disease Based on Fine Structure Analysis
}

\author{
Aaron W. Miller ${ }^{1 *}$, Patricia Blackwelder ${ }^{2,3,4}$, Husain Al-Sayegh ${ }^{2,3}$, Laurie L. Richardson ${ }^{1}$ \\ 1. Department of Biological Sciences, Florida International University, Miami, Florida 33199 USA \\ 2. University of Miami Center for Advanced Microscopy (UMCAM), Miami, Florida 33124, USA \\ 3. Marine Geology and Geophysics, University of Miami, Miami, Florida 33149,USA \\ 4. Nova Southeastern University Oceanographic Center, Dania, Florida 33004,USA \\ * Corresponding author: email addresses: aaron.miller@fiu.edu, richardl@fiu.edu, pblackwelder@rsmas.miami.edu, \\ h.alsayegh@miami.edu
}

\author{
Received 15-VII-2011. C Corrected 12-XII-2011. Accepted 20-XII-2011.
}

\begin{abstract}
In many diverse ecosystems, ranging from natural surfaces in aquatic ecosystems to the mammalian gut and medical implants, bacterial populations and communities exist as biofilms. While the process of biofilm development has been well-studied for those produced by unicellular bacteria such Pseudomonas aeruginosa, little is known about biofilm development associated with filamentous microorganisms. Black band disease (BBD) of corals is characterized as a polymicrobial biofilm (mat) community, visually-dominated by filamentous cyanobacteria. The mat migrates across a living coral host, completely lysing coral tissue and leaving behind exposed coral skeleton. It is the only known cyanobacterial biofilm that migrates across a substratum, thus eliciting questions about the mechanisms and unique characteristics of this system. Fragments of the coral Montastraea annularis, five artificially infected with BBD and two collected from a naturally BBD-infected colony, were used to address these questions by detailed examination using scanning and transmission electron microscopy (SEM and TEM). In areas close to the interface of coral tissue and the mature disease band two types of clusters of cyanobacteria were observed, one with random orientation and one with parallel orientation of filaments. The latter exhibited active secretion of extracellular polysaccharide (EPS) while the randomly oriented clusters did not. Within the well developed band cyanobacterial filaments were observed to be embedded in EPS and were present as layers of filaments in parallel orientation. These observations suggest that BBD cyanobacteria orient themselves and produce EPS in a sequential process during migration to form the complex BBD matrix. Rev. Biol. Trop. 60 (Suppl. 1): 21-27. Epub 2012 March 01.
\end{abstract}

Key words: black band disease, biofilm, microbial mat, corals.

Black band disease (BBD) of corals exists as a thick biofilm, or thin mat, that migrates across coral colonies completely degrading coral tissues (Rützler et al. 1983). While the mechanisms that control band migration and development are not known, this horizontal migration of the intact biofilm/mat community, and it's migration across a living coral host, are unique (Richardson 1996). The pathogenicity of a polymicrobial mat dominated by filamentous cyanobacteria is also unique and is an important aspect of the disease.
Biofilms have been studied in depth for decades, and in natural ecoystems they can be found on virtually any surface in aquatic environments. Much interest has been focused on pathogenic biofilms, which are very common for animal (including human) hosts. Evidence suggests that biofilm-forming bacteria exist in a transient, planktonic form, which colonizes a surface to produce a biofilm (Wolcott and Ehrlich 2008). Bacteria growing in biofilms differ markedly from their free-living counterparts. One important difference is the excretion 
of extracellular polysaccharides (EPS) by biofilm-associated microorganisms, which facilitates the adhesion of microorganisms within the biofilm (Rickard et al. 2003). Such EPS secretion, which is a conspicuous component of BBD, may play an important role in forming the complex polymicrobial structure associated with this disease. It is well-documented that, when associated in biofims, bacteria exhibit an increased resistance to fluctuating environmental conditions, including avoidance of antibiotics and antagonistic cells associated with host immune systems (Govan and Deretic 1996, Costerton et al. 1999, O'Toole et al. 2000). It has been estimated that $65 \%-80 \%$ of human diseases are caused by biofilms (Wolcott and Ehrlich 2008). The latter fact alone has made the initiation and development of biofilms important areas of research.

Perhaps the most well-studied of pathogenic biofilms are those associated with lung infections in individuals with cystic fibrosis, caused by the unicellular species Pseudomonas aeruginosa (O'Toole et al. 2000). Polymicrobial biofilm development has also been studied, for example focusing on biofilms associated with dental plaque, a system that may contain as many as 300 different species of microorganisms (Paster et al. 2001). Model systems have been used to directly examine the process of biofilm development in the laboratory. Such model systems have made use of both single and multiple species, including Escherichia coli, P. fluorescens, and Vibrio cholerae, among others (Pratt and Kolter 1998, Watnick et al. 1999). However, all of these model systems have focused on unicellular bacteria, and little is known about the development of biofilms associated with filamentous bacteria.

BBD is known to infect at least 64 scleractinian coral species worldwide, and is considered to be an important disease contributing to the loss of coral cover due to its often lethal, preferential infection of massive, reef-building corals (Rützler et al. 1983, Edmunds 1991, Kuta and Richardson 1996, Sutherland et al. 2004, Voss and Richardson 2006). It is caused by a polymicrobial biofilm, or very thin $(<1 \mathrm{~mm})$ mat, which can range from a few millimeters to several centimeters in width (Rützler and Santavy 1983, Carlton and Richardson 1995). The biomass of the mat is dominated by gliding, filamentous cyanobacteria of the newly described genus Roseofilum (Casamata et al., 2012) and may also contain members of the cyanobacterial genera Oscillatoria, Geitlerinema, Leptolyngbya and Phormidium (Cooney et al. 2002, Frias-Lopez et al. 2003, 2004, Sussman et al. 2006, Barneah et al. 2007, Myers et al. 2007). Together, BBD cyanobacteria provide the structural framework for the mat and have recently been shown to be directly involved in BBD pathobiology. BBD-associated coral mortality occurs as the contiguous band migrates across the coral colony, at a rate of three millimeters to one centimeter a day, lysing coral tissue and leaving behind exposed coral skeleton. This coral tissue lysis is aided by a cyanotoxin, microcystin, produced by BBD cyanobacteria (Richardson et al., 2007, 2009; Miller and Richardson 2011). Here we use SEM and TEM to examine the fine structure of the BBD biofilm/mat to elucidate mechanisms that may contribute to the development and progression of the BBD mat across a coral colony.

\section{MATERIALS AND METHODS}

Sample collection and preparation for microscopy are described in detail in Miller et al. (2011). Briefly, seven BBD-infected fragments of the coral Montastraea annularis species complex were used for this study. Five fragments, from aquarium maintained colonies or from apparently healthy colonies on Horseshoe Reef at Lee Stocking Island, Bahamas, were artificially infected with freshly collected BBD. The resultant band was allowed to migrate for a period of 2-3 days after which the fragment was immersed in a fixture composed of $2 \%$ glutaraldehyde in sodium cacodylate buffered seawater. The remaining two fragments, collected from a naturally BBD-infected coral colony at Algae Reef in Key Largo, Florida, which appeared to have been infected over several seasons due to the significant tissue 
loss observed on the colony, were fixed immediately after collection. Natural and artificial infections have previously been shown to be indistinguishable both macroscopically (Richardson et al. 2009) and at the fine structural level (Miller et al. 2011). In the laboratory after a buffer wash all fragments were post-fixed in $1 \%$ osmium tetroxide, rinsed with buffer, dehydrated in a graded series of ethanols, and processed for SEM (critical point dried) and/or TEM (embedded in Spurr@ resin) analysis (see Miller et al., 2011).

\section{RESULTS}

Examination of the BBD biofilm/mat on infected fragments using SEM revealed that, despite the homogenous appearance of the disease band macroscopically, the mat exhibited spatial heterogeneity. In both artificially and naturally infected coral fragments cyanobacterial filaments were found millimeters ahead of the mature band (Figure 1). These filaments were present as loose aggregations that formed clusters between and underneath coral tissue layers, and could be seen separating the coral tissue from the coral skeleton. Some of the clusters (Figure 1A) consisted of cyanobacteria that appeared to be randomly oriented relative to each other, with few filaments in alignment, and had no associated EPS. Other clusters were observed to exhibit active EPS secretion that was associated with individual filaments that were oriented primarily in parallel, with groups of filaments generally aligned together (Figure 1B). In some cases, such filaments appeared to be enveloped in EPS, but there was no distinct layer of EPS matrix holding the filaments together.

The differentiation between EPS and nonEPS producing BBD cyanobacteria can be clearly seen in TEM micrographs (Figure 2). Some clusters of cyanobacteria penetrating through coral tissue had no ring of EPS surrounding each cyanobacterial filament (shown in cross-section in Figure 2A), while other cyanobacteria, also present in clusters and penetrating through coral tissue, had no apparent ring of EPS (Figure 2B).

Examination of the BBD in the center of the mat (between the leading edge and the exposed coral skeleton behind the band) revealed a much more organized band structure (Figure 3). Thick layers of cyanobacteria were observed to be oriented in parallel and were in much closer physical association than those in the coral tissue in front of the band, providing a distinct structural framework (Figure 3A). It

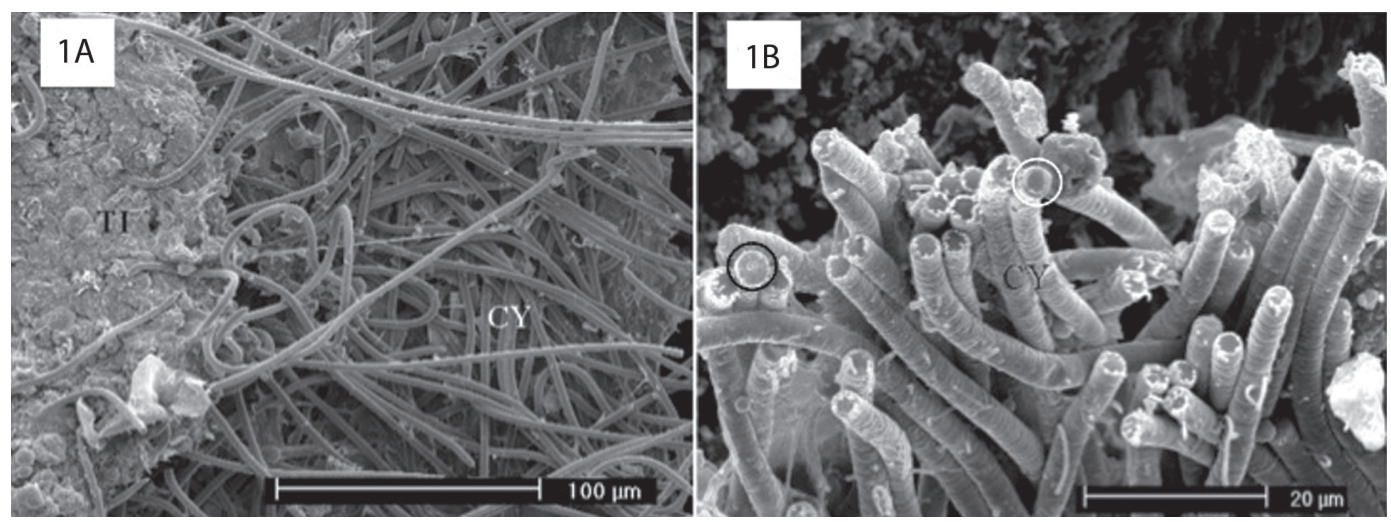

Fig. 1. SEM images of coral tissue in front of the leading edge of the BBD mat. A. Cluster of cyanobacteria exhibiting random orientation, and no apparent EPS, underneath the coral tissue. B. Close up of EPS secretion associated with individual cyanobacterial filaments within a cluster of filaments with parallel orientation. White circle indicates ringed EPS structure around terminal cell; black circle indicates a disk of EPS covering the terminal cell. CY: cyanobacteria, TI: coral tissue. 


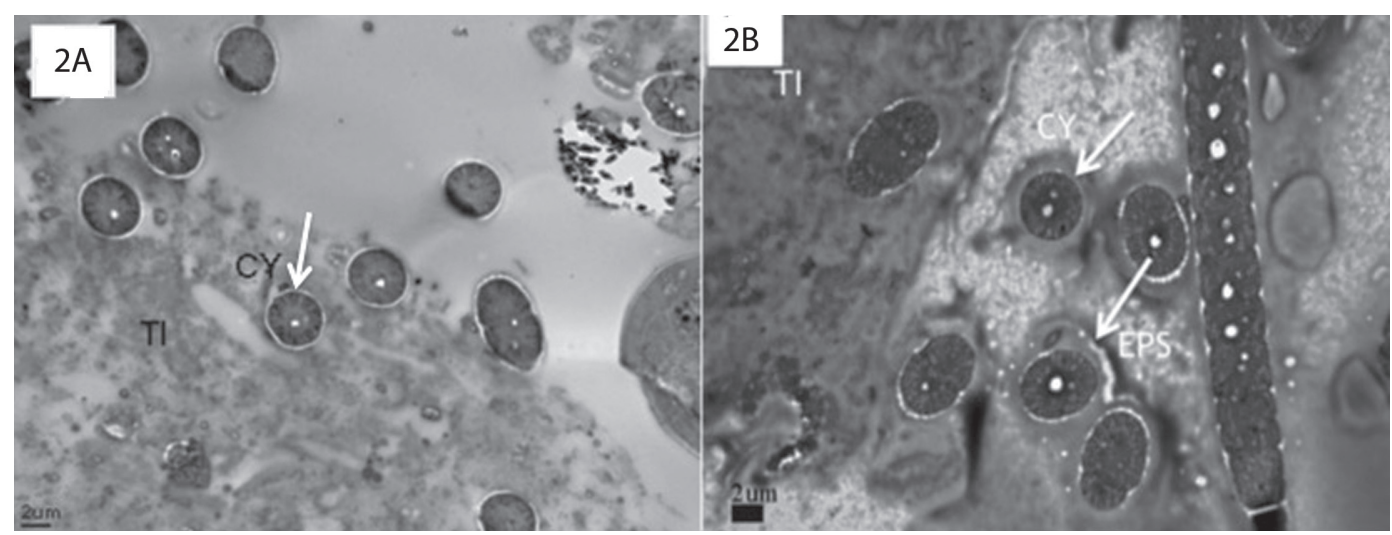

Fig. 2. TEM images of EPS secretion from cyanobacteria at the interface with coral tissue and the disease band. A. Cross-section of cyanobacteria within coral tissue exhibiting no ring of EPS surrounding the filament. B. Cross-section of cyanobacteria within coral tissue surrounded by a ring of EPS. CY: cyanobacteria, TI: coral tissue, EPS: exopolysaccharides.

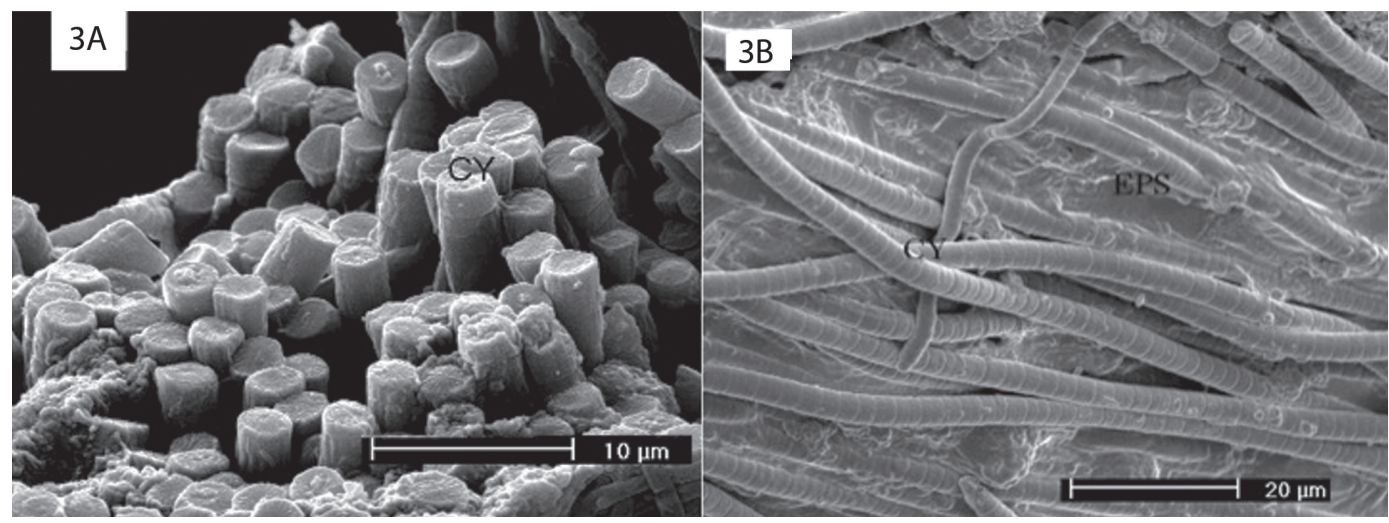

Fig. 3. Development of EPS matrix in the BBD biofilm/mat. A. Layering of cyanobacterial filaments in parallel orientation on top of coral tissue at the interface between coral tissue and the mature BBD mat. B. Parallel BBD filaments embedded in EPS matrix. EPS: exopolysaccharides, CY: cyanobacteria.

was also observed that parallel filaments were embedded in a distinct EPS matrix (Figure 3B).

\section{DISCUSSION}

In this study, SEM and TEM examination of BBD-infected coral fragments revealed that clusters of cyanobacteria were present millimeters ahead of the pathogenic disease band. These clusters could be seen penetrating through (Figure 2), and underneath (Figure 1A) coral tissue. Previous studies have shown that BBD cyanobacteria are able to penetrate into coral tissue (Rützler et al. 1983, Barneah et al. 2007, Sato et al. 2009, Miller et al. 2011), and into coral skeleton (Miller et al. 2011).

The BBD cyanobacteria ahead of the mature band in the current study were aggregated in clusters that exhibited both primarily random (Figure 1A), or primarily parallel (Figure 1B), orientation. In these areas of the infected coral the BBD cyanobacteria either 
exhibited no EPS secretion (Figure 1A, 2A), or were associated with EPS on the surface of filaments (Figure 1B, 2B). Some of these clusters were fully embedded in EPS (Figure 3B).

There appeared to be a transition between the clusters of cyanobacteria in the tissue in front of the band, and the fully formed band itself. Specifically, randomly oriented, nonEPS forming clusters appeared to transition into parallel-oriented filaments that produced EPS, which then appeared to transition into more closely packed, layered clusters. In some of the transitional clusters where cyanobacteria exhibited parallel orientation there was significant layering, leading to aggregations that were several filaments thick (Figure 3A), which could provide a distinct structural framework for the growth of associated microorganisms in the BBD mat. These aggregations can be considered to be biofilms, which may further aggregate to form the mature mat.

Previous studies have suggested that BBD cyanobacteria, which are the dominant component of the BBD community, provide the structural framework of the BBD mat (Rützler and Santavy 1983). This hypothesis is supported by the results presented in the current study. Furthermore, the observed layering of filaments, and differentiation in EPS production, are consistent with the results of other studies focused on formation of biofilms. In well-studied, model biofilm systems composed of unicellular bacteria, the development of the biofilm occurs after free-living, planktonic bacteria attach to a surface and begin to secrete EPS. This EPS then embeds and surrounds the biofilm-forming bacteria in an adhesive matrix (Gacesa 1998, Kolenbrander et al. 1999, Flemming et al. 2000, O'Toole et al. 2000, Handley et al. 2001, Rickard et al. 2003). Mutations in the genes controlling EPS secretion lead to both altered attachment behavior and biofilm formation, further strengthening this relationship between EPS and biofilm formation (Makin and Beveridge 1996, Genevaux et al. 1999).

In contrast to the temporal basis of unicellular biofilm formation, it appears that filamentous BBD cyanobacteria form the biofilm/ mat in a spatial, longitudinal fashion. As BBD cyanobacteria migrate into tissue ahead of the band, they appear to stop producing EPS. The clusters of filaments behind these leading BBD cyanobacteria produce small amounts of EPS that accumulate and bind the filamentous matrix into new biofilm that thickens to become a mat. This secretion of EPS embeds not only the surrounding cyanobacteria but also the many other BBD-associated bacteria into a distinct layer that constitutes the mature biofilm/mat.

Our results reveal new insights into the development of the BBD biofilm/mat and its association with coral tissue in apparently healthy areas ahead of the band. One of the most intriguing questions about BBD biofilm/ mat remains unanswered - what is the cue that causes the mat to migrate across and through coral tissue?

\section{RESUMEN}

En muchos ecosistemas diversos, que van desde ecosistemas acuáticos hasta los intestinos de mamíferos e implantes médicos, las poblaciones y comunidades de bacterias existen como biopelículas (biofilms). El proceso de desarrollo de las biopelículas ha sido bien estudiado para aquellos producidos por bacterias unicelulares como $\mathrm{Pseu}$ domonas aeruginosa, pero se conoce muy poco acerca del desarrollo de biopelículas asociadas con microorganismos filamentosos. La Enfermedad de Banda Negra (EBN) de coral es caracterizada como una comunidad polimicrobiana que forma una biopelícula (lecho), visualmente-dominada por una cianobacteria filamentosa. El lecho migra a través de un huésped de coral vivo, rompiendo completamente el tejido del coral y dejando atrás el esqueleto de coral expuesto. Es la única biopelícula cianobacteriana que migra a través de un sustrato, por lo tanto esto genera preguntas acerca de los mecanismos y las características únicas de este sistema. Fragmentos del coral Montastraea annularis, cinco artificialmente infectados con EBN y dos colectados de una colonia EBN-infectada, fueron usados para abordar estas preguntas mediante exámenes detallados con microscopía electrónica de barrido y de transmisión (MEB y MET). En zonas cercanas a la interfaz de tejido del coral y la banda de la enfermedad madura, se han observado dos tipos de grupos de cianobacterias, uno con orientación aleatoria y otro con una orientación paralela de los filamentos. Este último exhibe la secreción activa de polisacáridos extra-celulares (PEC), mientras que los grupos orientados al azar no lo hicieron. Dentro de la banda de filamentos cianobacterianas bien desarrollados se observó que estaban integradas en 
PEC y que se presentaban como capas de cianobacteria con orientación paralela. Estas observaciones sugieren que la cianobacteria de EBN se orienta a sí misma y produce PEC en un proceso secuencial durante la migración para formar la matriz complejo de EBN.

Palabras clave: enfermedad banda negra, biopelícula, lecho microbiano, corales

\section{REFERENCES}

Barneah O., E. Ben-Dov, E. Kramarsky-Winter \& A. Kushmaro. 2007. Characterization of black band disease in Red Sea stony corals. Environ. Microbiol. 9: 1995-2006.

Carlton, R.G. \& L. L. Richardson. 1995. Oxygen and sulfide dynamics in a horizontally migrating cyanobacterial mat: black band disease of corals. FEMS Microbiol. Ecol. 18: 155-162.

Casamata, D.A., D. Stanić, M. Gantar \& L.L. Richardson. 2012. Characterization of Roseofilum reptotaenium (Cyanobacteria, Oscillatoriales) gen. et sp. nov. isolated from Caribbean black band disease. Phycologia: in press.

Cooney R.P., O. Pantos, M.D.A Le Tissier, M.R. Barer, A.G. O’Donnell \& J.C. Bythell. 2002.

Characterization of the bacterial consortium associated with black band disease in coral using molecular microbiological techniques. Environ. Microbiol. 4: 401-413.

Costerton, J.W., P.S. Stewart \& E.P. Greenberg. 1999. Bacterial biofilms: a common cause of persistent infections. Science 284: 1318-1322.

Edmunds, P.J. 1991. Extent and effect of black band disease on a Caribbean reef. Coral Reefs 10(3): 161-165.

Flemming, H.C., J. Wingender, C. Mayer, V. Korstgens \& W. Borchard. 2000. Cohesiveness in biofilm matrix polymers. Community Structure and Cooperation in Biofilms. SGM Symposium Series 59, Cambridge, UK.

Frias-Lopez J.A., G.T. Bonheyo, Q.S. Jin \& B.W. Fouke. 2003. Cyanobacteria associated with coral black band disease in Caribbean and Indo-Pacific reefs. Appl. Environ. Microbiol. 69: 2409-2413.

Frias-Lopez J.A., J.S. Klaus, G.T. Bonheyo \& B.W. Fouke. 2004. Bacterial community associated with black band disease in corals. Appl. Environ. Microbiol. 70: 5955-5962.
Gacesa, P. 1998. Bacterial alginate biosynthesis: recent progress and future prospects. Microbiol. 144: 1133-1143

Genevaux, P., P. Bauda, M.S. DuBow \& B. Oudega. 1999. Identification of the $\mathrm{Tn} 10$ insertions in the $r f a G, r f a P$, and galU genes involved in lipopolysaccharide core biosynthesis that affect Escherichia coli adhesion. Arch. Microbiol. 172: 1-8.

Govan, J.R.W. \& V. Deretic 1996. Microbial pathogenesis in cystic fibrosis: mucoid Pseudomonas aeruginosa and Burkholderia cepacia. Microbiol. Rev. 60: $539-574$.

Handley, P.S., A.H. Rickard, N.J. High \& S.A Leach. 2001. Coaggregation- is it a universal biofilm phenomenon? Biofilm Community Interactions: Chances or Necessity? Bioline Press, Cardiff, UK.

Kolenbrander, P.E., R.N. Anderson, D.L. Clemens, C.J. Whittaker \& C.M. Klier. 1999. Potential role of functionally similar coaggregation mediators in bacterial succession. Dental Plaque Revisited. Bioline Press, Cardiff, UK.

Kuta, K.G. \& L. L. Richardson. 1996. Abundance and distribution of black band disease on coral reefs in the northern Florida Keys. Coral Reefs 15: 219-223.

Makin, S.A. \& T.J. Beveridge. 1996. The influence of A-band and B-band lipopolysaccharide on the surface characteristics and adhesion of Pseudomonas aeruginosa to surfaces. Microbiology 142: 299-307.

Miller, A.W., P. Blackwelder, H. Al-Sayegh \& L.L. Richardson. 2011. Fine-structural analysis of black band disease-infected coral reveals boring cyanobacteria and novel bacteria. Dis. of Aquat. Organ. 93: 179-190.

Miller, A.W. \& L.L. Richardson. 2011. Fine-structural analysis of BBD infected coral and coral exposed to the BBD toxins microcystin and sulfide. J. Invert. Path.: in press.

Myers J.L., R. Sekar \& L.L. Richardson. 2007. Molecular detection and ecological significance of the cyanobacteria Geitlerinema and Leptolyngbya in black band disease of corals. Appl. Environ. Microbiol. 73: 5173-5182.

O’Toole, G.A., H.B. Kaplan \& R. Kolter. 2000. Biofilm formation as microbial development. Ann. Rev. Microbiol. 54: 49-79.

Paster, B.J. et al. 2001. Bacterial diversity in human subgingival plaque. J. Bacteriol. 183: 3770-3783. 
Pratt, L.A. \& R. Kolter .1998. Genetic analysis of Escherichia coli biofilm formation: defining the roles of flagella, motility, chemotaxis, and type I pili. Mol. Microbiol. 30: 285-294.

Richardson, L.L. 1996. Horizontal and vertical migration patterns of Phormidium corallyticum and Beggiatoa spp. associated with black band disease of corals. Microb. Ecol. 32: 323-335.

Richardson, L.L., R. Sekar, J.L. Myers, M. Gantar, E.R. Remily, L.T. Kaczmarsky, J.D. Voss, G.L. Boyer \& P.V. Zimba. 2007. The presence of the cyanobacterial toxin microcystin in black band disease of corals. FEMS Microbiol. Ecol. 272:182-187

Richardson, L.L., A.W. Miller. E. Broderick, L.T. Kaczmarsky, M. Gantar, D. Stanić \& R. Sekar. 2009. Sulfide, microcystin, and the etiology of black band disease. Dis. Aquat. Org. 87:79-90

Rickard, A.H., P. Gilbert, N.J. High, P.E. Kolenbrander \& P.S. Handley. 2003. Bacterial coaggregation: an integral process in the development of multi-species biofilms. Trends Microbiol. 11: 94-100.

Rützler, K. \& D. Santavy. 1983. The black band disease of Atlantic coral reefs. P.S.Z.N.I: Mar. Ecol. 4: 301-319.

Rützler, K., D. Santavy \& A. Antonius. 1983. The black band disease of Atlantic coral reefs III: distribution, ecology, and development. P.S.Z.N.I: Mar. Ecol. 4: 329-358.

Sato Y., B.L. Willis \& D.G. Bourne. 2009. Successional changes in bacterial communities during the development of black band disease on the reef coral, Montipora hispida. ISME J. 1-12.

Sussman M., D.G. Bourne \& B.L. Willis. 2006. A single cyanobacterial ribotype is associated with both red and black bands on diseased corals from Palau. Dis. Aquat. Org. 69: 111-118.

Sutherland, K.P., J.W. Porter \& C. Torres. 2004. Disease and immunity in Caribbean and Indo-Pacific zooxanthellate corals. Mar. Ecol. Prog. Ser. 266: 273-302.

Voss, J.D. \& L.L. Richardson. 2006. Nutrient enrichment enhances black band disease progression in corals. Coral Reefs 25: 569-576.

Watnick, P.I., K.J. Fullner \& R. Kolter. 1999. A role for the mannose-sensitive hemaglutinin in biofilm formation by Vibrio cholerae El Tor. J. Bacteriol. 181: 3606-3609.

Wolcott, R.D. \& G.D. Ehrlich. 2008. Biofilms and chronic infections. J. Amer. Med. Assoc. 299: 2682-2684. 
